\title{
Tourism development in China since 1949: a regime perspective
}

\section{Lingling $\mathrm{Bi}^{\star}$}

Department of Earth and Environmental Sciences, University of Leuven, Celestijnenlaan 200E Box 2409, 3000 Leuven, Belgium

and

School of Tourism and Research Institute of Human Geography, Xi'an International Studies University, No. 1 South Wenyuan Road Box 75, 710128 Xi'an, China

Email: Lingling.Bi@kuleuven.be

*Corresponding author

\section{Dominique Vanneste}

Department of Earth and Environmental Sciences, University of Leuven, Celestijnenlaan 200E Box 2409, 3000 Leuven, Belgium

Email: Dominique.Vanneste@kuleuven.be

\section{Jan van der Borg}

Department of Earth and Environmental Sciences, University of Leuven, Celestijnenlaan 200E Box 2409, 3000 Leuven, Belgium and

Department of Economics, University of Venice,

San Giobbe 873, 20123 Venice, Italy Email: Jan.vanderBorg@kuleuven.be

\begin{abstract}
The People's Republic of China has experienced great economic, political and socio-cultural changes since its founding in 1949, which in turn have considerably impacted every aspect of the Chinese society. Adopting a regime perspective, the paper discusses China's tourism development against these backdrops, with an aim to disentangle the relation between tourism development and the broader context. In the light of the heritage-tourism-urban development strategy today, a special attention is given to tourism's (non)interaction with heritage and urban development, to examine the impact of the (lack of) internal dynamics on their development paths. In its attempt to answer the questions of 'why' and 'what' in China's tourism development, the paper aims to provide a panoramic view of the topic and the unique dialogism among tourism development, heritage conservation and urban development that underlines the appropriation and practice of tourism and heritage in contemporary China.
\end{abstract}


Keywords: tourism; China; regime; heritage conservation; urban development; transformation; governance; policy; socialist market economy; economic development; harmonious society.

Reference to this paper should be made as follows: Bi, L., Vanneste, D. and van der Borg, J. (xxxx) 'Tourism development in China since 1949: a regime perspective', Int. J. Tourism Policy, Vol. X, No. Y, pp.000-000.

Biographical notes: Lingling $\mathrm{Bi}$ is a Lecturer at the School of Tourism and Research Institute of Human Geography, Xi'an International Studies University, China. She is currently a $\mathrm{PhD}$ candidate in the Division of Geography and Tourism, University of Leuven (KU Leuven), Belgium, conducting research on cultural heritage conservation, heritage tourism and urban development.

Dominique Vanneste is an Associate Professor in Economic Geography and Tourism at the University of Leuven (KU Leuven). She is a Director for the Erasmus Mundus program in Sustainable Territorial Development as well as Director of KU Leuven - LRD Division ASTOR (Association for Tourism Research). Furthermore, she is representative of KU Leuven with the UNITWIN-UNESCO network and the UNWTO Knowledge Network. Her work focuses on tourism from a local/regional development and network perspective, as well as heritage with an emphasis on identity/sense of place and stakeholder participation.

Jan van der Borg teaches Tourism Management and Marketing at the University of Leuven (KU Leuven), where he currently holds the Toerisme Vlaanderen Chair in Tourism Management, and Tourism Economics at the University Ca'Foscari of Venice. He is member of the Board of EURICUR and has coordinated and still coordinates a number of international and national research programs in the field of tourism. Among his research interests are the implications of the concept of sustainable tourism development in general, and that of the tourist carrying capacity, in particular for cities.

\section{Introduction}

The past three decades have witnessed rapid tourism development in China, along with its sustained economic growth and closer integration into the world. In the Travel and Tourism Competitiveness Index 2015 released by the World Economic Forum (2015), Mainland China ranks 17 among 141 world economies, a significant jump from the 28th position in 2013. According to UNWTO (2015), China maintains its status as the no. 1 top source market and the no. 4 top tourist destination in 2014. Similarly, China's domestic tourism has been growing exponentially over time. In 1995, China had only 629 million travels that generated an income of $¥ 137.6$ billion (US\$16.5 billion) (CNTA, 1996). However, in 2014, domestic tourist visits totalled 3.61 billion, with a tourism revenue of $¥ 3031.2$ billion (US $\$ 493.5$ billion), an increase of $10.7 \%$ and $15.4 \%$ respectively over the previous year (CNBS, 2015).

Viewing the present scale, one can hardly imagine the strong anti-tourism sentiment of the state six decades ago when China was newly founded. Indeed, "[t]Tourism does 
not follow a single model for development. Its organisation and administration depend on particular national and local needs and circumstances" [Lew and Yu, (1995), p.61].

One of such circumstances to better grasp China's tourism development is the dramatic economic, political and socio-cultural changes since its founding in 1949, especially since the 1978 reform and opening up, which have considerably impacted every aspect of the Chinese society, including tourism. With the founding of China in 1949, a party-state political structure has been established, with the Communist Party of China (CPC) exercising absolute power over issues at all levels of society. The central government, the State Council, leads and supervises the local governments, with the latter reporting to the former. The centralised political system ensures that "society is placed under the state and the state is overseen by the CPC" [Airey and Chong, (2011), p.32]. Since 1978, a gradual decentralisation of the state power and establishment of a market mechanism in China has been witnessed. However, given the socialist political system, the state, via policy making, continues to play a pivotal role in China's tourism development. It is with such an understanding and against such a background that a complete picture of China's tourism development can be mostly secured.

This paper investigates China's tourism development since 1949. The purpose is two-fold. First, it endeavours to disentangle the relation between tourism development and the broader context it is embedded in, to better understand its development path till today. Second, in the context of the promoted heritage-tourism-urban development strategy in China today (China Economy, 2014; MC and CNTA, 2009; SC, 2001, 2014; Shan, 2010; Xu, 2016), a special attention is given to tourism's (non)interaction with heritage conservation and urban development, to see whether and, if so, how they influence each other's development paths. The tension between heritage and urban development has long existed, but the nature of this relation changes over time due to varied perceptions and approaches in different historical contexts. In recent decades, tourism has started to get involved with both heritage and urban development. Theoretically, its mutual tie with both provides tourism with the potential as a mediating power in between. But the reality is more complex, relating to such issues as the perceptions of the three elements among the different stakeholders, the shift in political agendas, the roles of heritage and tourism in urban development, and the tourism impacts on heritage conservation. The exploration of the dynamics among them sheds light not only on the tourism development but also on its changing roles between heritage conservation and urban development.

A regime perspective is adopted to achieve these ends. Originating in a political economy frame, a regime is conceptualised as an autonomous force that mediates between basic causal factors and outcomes (Stone, 1993). However, its applications indicate a strong focus on the analysis of internal dynamics at the expense of that of external factors (Haggard and Simmons, 1987; Lauria, 1997; Mossberger and Stoker, 2001; Tretter, 2008; Ward, 1996). By examining both the broader setting and the internal dynamics which have shaped China's tourism development, this paper hopes to narrow the gap.

\section{The regime concept}

The regime concept started to emerge in the 1970s and early 1980s (Elkin, 1985; Fainstein et al., 1983; Haas, 1980a, 1980b; Keohane and Nye, 1977; Ruggie, 1975; 
Young, 1980). It was popularised with the publication of the special issue of International Organization on international regimes in 1982 and the publication of Regime Politics: Governing Atlanta 1946-1988 by Clarence Stone in 1989. Since then, the concept has been applied and adjusted in different fields and contexts at various scales (Edwards and Prins, 2014; Gjerde et al., 2008; Henig et al., 1999; Inbar, 1995; Konrad et al., 2008; Porter, 2002; Stokke et al., 2005; Stone, 1998), which has contributed to its further development.

In the field of international relations, the often-cited consensus definition refers a regime as "sets of implicit or explicit principles, norms, rules, and decision-making procedures around which actors' expectations converge in a given area" [Krasner, (1982b), p.186], though many other scholars have contributed to the conceptual formation and development of the regime concept (Haas, 1980a; Keohane and Nye, 1977; Levy et al., 1995; Maswood, 2000; Young, 1980, 1982). In urban regime analysis, a regime is defined by Stone as "the informal arrangements by which public bodies and private interests function together in order to be able to make and carry out governing decisions" [Stone, (1989), p.6], and it has also been used and adjusted by many others (DiGaetano and Klemanski, 1993; Jones and Dugdale, 2001; Konrad et al., 2008; Mossberger and Stoker, 2001; Ploberger, 2012).

As indicated above, the concept has been applied and adapted in different research disciplines and contexts at various scales. What about conceptual coherence? First, a regime is relatively stable, which distinguishes it from concepts like 'arrangement' that is often one-shot or temporary (Keohane and Nye, 1977; Krasner, 1982b). However, the relative stability neither implies that actors always comply with the norms and rules (Young, 1982), nor indicates uniformity or complete consensus over values, perceptions or practices among actors. Regime dynamics implies the constant negotiations between forces for change and forces for continuity (Stone, 1989). It is the dynamics under uniformity that leads to cooperation, and the power dynamics in the regime affects the way and the degree of cooperation among actors (Maswood, 2000). This leads to the second feature: a regime is not only regulating or governing, but also structuring and empowering.

A regime is empowering in the sense that for its members, a regime forms a governing coalition and creates the governing capacity that each of them is part of. It helps facilitate cooperation and achieve coordinated efforts which are otherwise difficult to realise over diversified interests, power dynamics, and uncertainties about each other (Haggard and Simmons, 1987; Stone, 1989). The word 'structuring' emphasises that "even relatively durable relationships undergo a continuing process of modification", during which members adjust to each other and change accordingly [Stone, (1989), p.181]. In other words, the internal dynamics helps maintain the stable set of relationships, but it can also force changes upon its members and correspondingly the stable set of relationships, i.e. the structure. Thus, a new regime may appear. Such an understanding gives rise to its third feature, regime significance.

Regime significance characterises the regime concept. As early as the start of the international regime research, a debate was initiated to address such a concern. Three schools of thoughts were provoked concerning the degree of regime significance: conventional structural, modified structural and Grotian (Krasner, 1982b). ${ }^{1}$ Though they agree on the basic causal variables at work, most prominently power and interests, for regime development, they disagree with each other on the extent that a regime makes a difference. Conventional structuralism considers it insignificant as "a phenomenon whose 
presence cannot be assumed and whose existence requires careful explanation"; however, the Grotian school considers it significant as "a pervasive and significant phenomenon in the international system" [Krasner, (1982b), p.194]. The modified structuralism, adopted by most of the researchers (Krasner, 1982b), takes a position in between, acknowledging the significance of basic causal variables, but at the same time arguing that regimes do play a role. One way to demonstrate their autonomy, according to Krasner, is through lags, which refer to "situations in which the relationship between basic causal variables and regimes becomes attenuated" [Krasner, (1982a), p.501]. Typical examples are the situations in which power and interests change, but regimes do not (Krasner, 1982a), or regimes change, but perceptions, visions, and practices of the old regimes still linger on.

If the causal variables justify the regime development, the external factors provide the structural environment for a regime. Derived from a political economy approach, the regime concept endeavours to find a middle way between pluralism that considers "governmental authority is adequate to make and carry out policies" and structuralism that assumes "the mode of production as pervading and dominating all other spheres of activity, including politics" [Stone, (1993), p.2]. Thus, a regime is conceptualised as an 'organism' that mediates between basic causal factors and outcomes (Stone, 1993). The external causal factors vary, but generally referred to the contexts that the studied regime is related to or embedded in, namely the socio-cultural, economic, and political environments (DiGaetano and Klemanski, 1993; Stone, 1989). It is at this point that the regime concept receives much criticism, for both the international regime and urban regime literature implies a general neglect of the context in regime (trans)formation (Haggard and Simmons, 1987; Lauria, 1997; Mossberger and Stoker, 2001; Ward, 1996), though some research do acknowledge the socio-cultural, economic, and political factors at work (Collins, 2008; Stone, 1993; Tretter, 2008).

The paper discusses the tourism development in China since 1949, in relation to heritage conservation and urban development, from a regime perspective. The regime concept is perceived in the paper as a system which contains regulation processes in order to maintain its structure - the stable set of relations among tourism, heritage conservation and urban development. The internal dynamics among the elements helps maintain this stability, but may also bring about changes in each individual element, subsequently in the structure and ultimately of the regime itself. A second important factor to enforce regime transformation is the broader context, i.e. the socio-cultural, economic, and political environments. China exhibits three distinct periods since 1949, namely 1949-1978, 1978-end of the century, and the 21st century onwards, which generate different tourism development, heritage conservation and urban development paths, with varied dynamics. Thus three successive regimes can be distinguished concerning the relationship among tourism development, heritage conservation and urban development in China, conditioned by both external factors and internal dynamics. The regime approach offers a long-term perspective on tourism development paths and helps understand the tourism development evolution not only from the broader setting, but also from its immediate environment, i.e. its changing relations with heritage conservation and urban development.

Within the scope of this paper, it is not possible to present a thorough regime and transformation analysis for the three regimes in a comprehensive way. Thus, the paper confines itself to the research question 'how the social-economic-political contexts affect the vision and practice of tourism development, and how tourism development interacts with heritage conservation and urban development in the process?' 


\section{The period of 1949-1978}

\subsection{Context}

The almost half-a-century war-torn period ended in 1949 with the founding of China in a centrally planned economic system and a party-state political system. The CPC exercised absolute power and enforced policy. The national economy - both supply and demand sides - was centrally controlled and planned, leaving no room for market intervention.

At the global scale, the world then was witnessing confrontation between the two ideological blocs led by the USA and the Soviet Union, and China naturally joined the latter. As a result, China was faced with diplomatic isolation and trade embargos by the US-led bloc from the very beginning (Airey and Chong, 2011). The breakup with the Soviet Union since mid-1950s made its integration into the international community even more difficult. This situation started to change only since the 1970s.

China started the industrialisation process immediately after its founding. Influenced by the Soviet Union, China prioritised the industrial development, especially the heavy industry. The tertiary industry, being considered unproductive, was ignored. According to Saich (2004), in the early 1950 s, $88 \%$ of the state capital investment was allocated to the heavy industry. During the First Five-Year Plan (1953-1957), China's economy started to develop. However, this was hampered by the Great Leap Forward (1958-1960), a radical movement to speed up industrial development through a high level of collectivisation. Combined with the natural disasters, the Great Leap Forward ended in failure with sharp decrease of GNP and some 30 million deaths (Dikötter, 2010; Shepherd and $\mathrm{Yu}, 2013)$. This was followed by the radical political movement, the Cultural Revolution (1966-1976). These interruptions greatly prevented China's economic growth.

The Cultural Revolution was actually an epitome of China's socialist ideologies in this period. Class struggle, politics-in-command, egalitarianism were of optimal importance for communist China (Airey and Chong, 2011). Culture and leisure had no place in people's life as being considered part of a bourgeois life style and contradictory to the communist frugal living doctrine. At the same time, public mobility was strictly controlled as a source of social instability.

The Cultural Revolution also vividly illustrated the perception of culture in this period. Culture and heritage were ignored and many of its cultural traditions were largely rejected (Sofield and Li, 1998; Yan and Bramwell, 2008). The demolition of many China's city walls in the urban development process can serve as an example (Chen, 2003; Whitehand and Gu, 2007). Through the 'four olds' campaign (old ideas, old culture, old customs and old habits) during the Cultural Revolution, cultural heritage was severely destructed and intellectuals were persecuted. As a result, culture and cultural heritage became a taboo and the cultural appreciation was greatly lost among the public.

\subsection{The tourism development: a political nature}

As mentioned above, China failed to integrate itself into the international community, which was undoubtedly a constraint for its tourism development. "Travel to the PRC was forbidden by the United States and many other western governments. China reciprocated by generally denying entry to most foreigners" [Richter, (1989), p.24]. However, it was this confrontation that served as a driver for the humble start of China's tourism. Tourism 
activities were arranged as a propaganda tool to nurture friendship and understanding with other nations and to promote socialist policies (Airey and Chong, 2011; Hall, 2001; Ryan et al., 2009a; Zhang, 1989). Along the same lines, the outbound travel was restricted to diplomats and government officials only (Wen and Tisdell, 2001), being considered both ideologically dangerous and economically wasteful (Arlt, 2006).

If the international environment restricted the tourism development, the domestic environment was simply against it. First and foremost, China practiced a centrally planned economic system, which in the first place made free tourism flow impossible. Second, the disregard for the service industry led to the discouragement of tourism development as not being considered as an appropriate form of economic activity (Wen and Tisdell, 2001). In fact, tourism planning was not generally undertaken (Ryan et al., 2009a) and little funding was accorded by the state. Till 1978, there were only 137 hotels with a total of 15,500 guest rooms (Han, 2009). Third, there was little tourism demand internally. The Chinese society was in a state of social unrest in the first half of the 20th century, which prevented most recreational travel (Sofield and Li, 1998). As mentioned before, the newly founded communist China then advocated for frugal living and against leisure and bourgeois lifestyle, which, to a certain extent, suppressed people's travel desires. In addition, China's economy did not grow much in that period and people still struggled for survival. Last, during the decade-long Cultural Revolution, travel was brought to a complete standstill (Xiao, 2006). All these unfavourable circumstances make people doubt the existence of tourism if without the diplomatic consideration.

As illustrated, tourism was perceived as a diplomatic tool instead of a proper form of economic activity. Thus, the inbound tourism of a political nature was placed on agenda. The general guidelines of the tourism policy were to promote the socialist achievements of China, to extend China's political influences in the world, and to enhance mutual understandings and friendships between the Chinese people and the people in the world (Airey and Chong, 2011).

All aspects of inbound tourism were tightly controlled by the national government to achieve this purpose, including visa application, travel arrangement and pricing (Airey and Chong, 2011; Zhang, 1995). In this centrally planned economic system, the state controlled all aspects of the national economy and resource allocation. The market and the private sector had no role to play in the management and supply of the tourism services under this system (Wen and Tisdell, 2001). The tourism development fell into the responsibility of the China Bureau of Travel and Tourism (CBTT), under the Ministry of Foreign Affairs. The two responsible operational travel agencies were China International Travel Service (CITS) and China Travel Service (CTS). The former was supervised by the CBTT and dealt with non-Chinese travellers, while the latter handled Chinese outside Mainland China and was taken care of by the Office of Overseas Chinese Affairs, under the State Council. These two travel agencies, as non-administrative organisations, formed part of the government bureaucracy (Zhang, 1995), receiving orders from their supervisors above and acting accordingly. ${ }^{2}$ In addition to the travel agencies, the transport industry, hotels, and tour organisations were all under state ownership and state control in one form or another (Wen and Tisdell, 2001). Therefore, cooperation was achieved via a system of command rather than reciprocity.

Tourists were mainly of two types, the permitted foreign guests and the Chinese from outside of Mainland China. An annual quota was set to limit the number of self-financed tourists (Airey and Chong, 2011). Nevertheless, tourists were treated as VIPs with "endless banquets, meetings with leaders, courtesy calls, and visits to working units" 
[Zhang, (1995), p.9], though the tourism infrastructure and service were in general of poor quality. As a matter of fact, visits to working units, factories and communes were highlighted to demonstrate the material achievements of communist China regardless of the interests of visitors (Sofield and Li, 1998). As Zhang (1995, p.9) pointed out, "it was the destination which selected the tourists rather than the tourists who chose the destination". With a diplomatic focus, tourism in general was operated at a loss, which had started to be aware of and addressed only since the 1970s (Airey and Chong, 2011).

\subsection{A lack of interaction}

In general, no close relation was identified and established among tourism, heritage and urban development in this period. The planned and political nature of tourism determined a lack of intercourse with both, while the tensions between heritage conservation and urban development were found from the very beginning. Thus the regime in this period features only partial relation and a lack of interaction among the three elements.

The tensions between heritage conservation and urban development did exist. Due to a general neglect of the past heritage and cultural traditions both from the government and among the public, many heritage buildings and building complexes were destructed to give way to urban development, such as the demolition of many of the city walls (Chen, 2003; Whitehand and Gu, 2007). Administrations responsible for heritage on the one hand and urban development on the other hand worked in parallel and purposive cooperation was non-existent since without a common agenda.

Tourism as an industry hardly existed in the planning economy. Being not considered as a proper economic activity, the role of tourism in urban development was not identified. Unavoidably, tourism activities, though quite limited, involved some heritage sites. However, due to the small scale and the lack of market competition, they failed to create a mutual relation, either constructive or destructive, as practiced in the market economy.

According to Stone (1989), a regime is referred as the informal arrangements through which both public and private sectors cooperate for governance. The assumption behind is that the public body, though in most cases formally responsible for governing, does not possess all the resources and scope of authority to practice governance. He further argues that cooperation can be realised in various ways. "It can be induced if there is an actor powerful enough to coerce others into it, but that is a rare occurrence, because power is not usually so concentrated" [Stone, (1989), p.8]. However, the assumption seems to be challenged in the case of communist China and the rare occurrence did happen. Under the planning economy, private sectors were absent in the fields of tourism, heritage and urban development. Government administrations and their subordinates took full charge of the issues concerned. Cooperation within sectors was achieved via a system of command rather than reciprocity, while cross-sector cooperation hardly existed due to a lack of common agendas. 


\section{The period of 1978-end of the century}

\subsection{Context}

In 1978, the Third Plenary Session of CPC's 11th National Congress was held, an epoch-making event for China's socio-cultural, economic and political development as well as international relations. Two important decisions were made: the shift from political struggle to economic modernisation and opening up to the outside world.

It was pointed out in the Third Plenary Session that overconcentration was a shortcoming in economic management and it called for a shift "under guidance from the leadership to lower levels so that the local authorities and industrial and agricultural enterprises will have great power of decision in management under the guidance of unified state planning" [CPC, (1978), p.52]. The decentralisation process, in terms of both central-local and state-market relations, has been going on since then and will predictably continue in the future.

Regarding the central-local relation, a turning point is the 1994 fiscal reform. A tax-sharing system between central and local governments was proposed to replace the revenue sharing system (Zhang, 1999). This initiative rendered local governments more autonomy to develop their own economy and increase local fiscal revenues, working as an economic entity with their own policy agendas and orientations ( $\mathrm{Ma}$ and $\mathrm{Wu}, 2005$; Su, 2015; Zhu, 2004).

In terms of the state-market relation, the private economy started to be officially recognised as complementary to public ownership since 1982 (Airey and Chong, 2011). As a result, the market and private enterprises positioned themselves in the national economy. The market-driven economic reform started with the household responsibility system in rural areas, then extended to urban industrial sectors, and further extended to other sectors to privatise production and distribution, decentralise decision-making, and authorise profit retention. ${ }^{3}$ Though with the ever deepening economic reform, the state continued to play an important role through macro-management and macro-planning. In China's socialist market economy, the operation of market mechanism is overseen by the state.

The tertiary industry in this period was differently perceived and practiced. Its development was facilitated by the rapid economic growth. This was met by the state with the decision in 1992 to further speed up its development. The rapid tourism development in the 1990s benefited from this initiative. The World Development Indicators from the World Bank shows that in 1999 the tertiary industry accounted for $39 \%$ of the GDP, while in 1981 the share of services was limited to $23 \%$ (WB, 2016).

Opening up to and a deeper contact with the world created more cultural awareness and nationalism, and facilitated China's cultural and heritage protection. China started to re-evaluate its past heritage since the reform and opening up. In 1982, the first Law on the Protection of Cultural Relics of the People's Republic of China was issued by the State Council to strengthen its protection, to inherit the splendid historical and cultural legacy and to conduct patriotic education. Since the 1980s more legal regulations have been introduced in the field (SACH, 2009). 


\subsection{The tourism development: an economic concern}

"The transition from one institutional form to another entails remaking the fundamental rules that shape economies, from formal regulations and laws to informal conventions and norms" [Nee, (1996), p.910]. The transition from the centrally planned economy to the socialist market economy in China had brought in new economic actors and new rules of cooperation and competition. The state power had weakened, though still prominent in the socialist market economy, with market exchange gradually replacing redistribution as the main economic mechanism.

The tourism industry figured the first among experiment sectors for economic reform in terms of both privatisation and decentralisation. Tourism was in fact the first sector to be injected with foreign funds and management (Sofield and Li, 1998). In 1979, foreign investment was encouraged in hotels and travel agencies and five years later, the decision was made to allow for the involvement of local governments, government agencies, collectives and individuals in tourism investment (Zhang, 1995). Unlike the previous period, coalitions among actors were mainly built upon reciprocity and negotiation, though the state continued to possess immense powers.

The tourism organisational structure was modified and the administration was decentralised. Immediately after the start of the reform, CBTT was renamed as the State General Administration for Travel and Tourism (SGATT) under the direct jurisdiction of the State Council. In 1981, it was replaced by the China National Tourism Administration (CNTA), mainly focusing on the macro-planning and macro-management. It was no longer involved in the tourism business operation, with travel services becoming independent business entities (Zhang, 1995). Local governments gradually possessed more autonomy and power in making tourism development decisions. The decentralisation facilitated the tourism development, but also made the overall coordination difficult with different interests and agendas behind (Wen and Tisdell, 2001). However, behind the picture, one needs to be aware that, in China, with its socialist market economy, the central state still played an important role in shaping agendas and driving the tourism development.

Tourism was shifted to be an economic industry with its political role gradually concealed, especially since 1986 when tourism was officially declared an economic activity to be included in the national plan (Ball et al., 2007; Zhang, 1995). The post-reform tourism development started with its perceived role as a foreign currency generator (Qiao, 1995) and a contributor to the economic modernisation. Therefore, inbound tourism was prioritised and promoted since the start. Between late 1978 and early 1979, Deng Xiaoping delivered a series of speeches to address the economic importance of tourism (Airey and Chong, 2011; Xiao, 2006). This was followed by a series of actions and policy initiatives, such as the two tourism conferences held in 1980 and 1981 to formulate the tourism development goals and guidelines (Gao and Zhang, 1983), and the inclusion of tourism in the Seventh Five-Year Plan (1986-1990) (Zhang, 1995; Zhang et al., 1999).

With the rapid economic development, China's domestic tourism market started to expand in the 1990s (Qiao, 1995). In response, the State Council issued a notice on actively promoting the domestic tourism in 1993. This was followed by the introduction of a five-day working week in 1995 and three week-long national holidays in 2000. In 1998, the tourism industry was for the first time considered as a new growth point in the national economy and over two-thirds of the provincial-level governments endeavoured 
to make tourism a pillar or key industry (Wu et al., 2000; Zhang and Lew, 2003). All these initiatives, in turn, furthered domestic tourism development. The Yearbooks of China Tourism Statistics (CNTA, 1996, 2001) show that in 1995, the number of domestic travellers was 629 million with a total expenditure of $¥ 137.6$ billion (\$16.5 billion), and the number increased to 744 million and $¥ 318$ billion (\$38 billion) respectively in 2000 . The booming domestic tourism undoubtedly injected new vitality into the national economy. According to Wen and Tisdell (2001), tourism had become one of China's largest industries, accounting for over 5\% of GDP at the turn of the millennium. Outbound tourism, though starting to develop, was out of the agenda in this period. Only with the approaching of the new century, outbound travel was gradually relaxed and then officially acknowledged (Arlt, 2006; Zhang, 1995).

\subsection{Tourism as an economic tie between heritage conservation and urban development}

The shift to the market economy and the increasing engagement with the world had brought dramatic changes to tourism, heritage and urban development. The regime in this period features a close economic tie among the three with tourism standing in between. The economic development priority promoted tourism and, subsequently, the recognition of the importance of heritage largely from an economic perspective. As a result, heritage was so greatly damaged, especially in the 1990s, in the urban development and tourism development processes that reflections on the relationship among tourism, heritage and urban development started to be made with the new century approaching.

A salient feature of this period is the active involvement of local governments and private sectors, with the changing central-local and state-market relations. The local governments, working as economic entities, gained more autonomy to develop their own economy with their own policy agendas and orientations ( $\mathrm{Ma}$ and $\mathrm{Wu}, 2005$; $\mathrm{Su}, 2015$; $\mathrm{Zhu}, 2004)$. To achieve the economic development, the private sector was brought into the coalition as they possessed the required financial resources. Concerning heritage conservation, the state-level decision and the advice from the State Administration of Cultural Heritage (SACH) was not always taken or taken as it was by the local authorities. Though a consensus on the mutual relationship was reached upon the fact that heritage conservation contributes to tourism development which facilitates urban economic development, the agendas favoured the economic development priority and the recognition of heritage as an economic tool.

In contrary to the pre-reform era, the post-reform period adopted a pro-urban strategy with the city being recognised as the node for economic organisation, thus enjoying great development momentum. Led by the rapid urban development process, China witnessed mass destruction of cultural heritage in the name of urbanisation and urban renewal (Zhen, 2009). Tourism, as an economic activity, was considered a big contributor to the urban economic growth and thus highlighted. This rapid tourism development, to some extent, positively impacted on the appreciation and protection of culture and heritage. When tourism became acceptable as a strategy for China's modernisation, the conservation of traditional culture and heritage was also approved to enhance the tourism development (Sofield and $\mathrm{Li}, 1998$ ), in addition to its role in strengthening nationalism and patriotism. According to Sofield and Li (1998, p.377-378), "one of the major 
consequences of the adoption of a national tourism policy being the restoration and rehabilitation of sites destroyed during the turbulent years of the Cultural Revolution".

However, in this paradigm, tourism's role in heritage conservation against urban development is very limited. The lack of cultural awareness in heritage tourism often led to the damage and commercialisation of heritage. Whenever conflicts appeared, tourism's economic role tended to be prioritised at the expense of heritage conservation (Cao, 2002; Li and Wang, 2000). As a consequence, China's heritage was most severely destroyed in the 1990s (Zhen, 2009), in the contexts of the rapid economic growth momentum, the acknowledgement of the greater role of tourism in the economic growth and urban development, and the booming domestic tourism development. In addition, in the pursuit of a modern life spurred by the market economy, the public's neglect to heritage and cultural tradition was further strengthened. These may help explain the pronounced decreasing of the number of heritage regulations issued in the 1990s compared to the previous decades (SACH, 2009). These challenges have led to the adjustment of each individual element and their relation in the new century, as culture is becoming increasingly important for a nation to position itself in the globalising world.

\section{The period of the 21st century onwards}

\subsection{Context}

Undeniably, the market-oriented economic reform since 1978 has brought China rapid socio-economic development and urban development in its pursuit of socialist modernisations. However, along with the development momentum, the socio-cultural, economic and environmental problems have also become more acute (Airey and Chong, 2011). The export-oriented extensive growth model has caused environmental degradation and key resource depletion. In addition, the widening gap and the imbalanced development between urban-rural areas and eastern-western regions call for correction and immediate actions.

In face of this situation, the new leadership (2003) put forward a new phase of development propagandas, namely 'the scientific outlook on development' and 'the harmonious society', which promote a 'people-centred' approach and a comprehensive, coordinated and sustainable mode of development. This signifies an important shift of official thinking from Mao's class struggle and Deng's economic priority to a balanced and scientific development today, at least theoretically. Though the economic growth continues to be very important, GDP will no longer be the sole measurement standard and development goal. In light of this, the urban policy has also been revised, with a slowed-down, people-centred urban development put forward. Cities start to be treated as 'a conglomeration of population' rather than simply an economic engine ( $\mathrm{Ma}$ and $\mathrm{Wu}$, 2005).

The ongoing globalisation has influenced the heritage and development strategy, both nationally and locally. At the national level, the rapid economic development in the context of globalisation has brought culture and heritage new roles to play when entering the 21 st century. Culture and heritage are harnessed to strengthen national identity and serve as a bond for national unity against the current socio-economic complication. In addition, cultural software has been promoted to better position the country in the world $(\mathrm{Hu}, 2007)$. In the statement issued by the Sixth Plenary Session of the Seventeenth 
Central Committee (CPC, 2011), it proposes to promote cultural awareness and cultural confidence, and to develop the soft power of the Chinese culture. At the urban level, as the global economy evolves, cities tend to distinguish themselves by resorting to culture and heritage to gain competitiveness. Thus, heritage is revaluated not just economically but also culturally, which has impacted the heritage practice and correspondingly its relation with tourism and urban development.

It is under these global and national contexts that heritage, tourism and urban development start to integrate.

\subsection{The tourism development: a sustainable agenda}

With a changing national and international environment, tourism has emerged as a multifunctional strategic industry to serve economic, socio-cultural, political and environmental needs. What's on the agenda in this period are 'red tourism', 'green tourism' and heritage tourism in reference to urban development.

The political role of tourism finds its best expression in the development of red tourism, the trip to the communist heritage sites shaped between 1921 and 1949, with an aim to stimulate nationalism and patriotism (He, 2005). The state is highly involved in both the supply and demand sides. On the one hand, it plays a role in planning and promoting the sites (GOCPC and GOSC, 2004, 2011). On the other hand, "red tourism is mostly officially organised and certain parts of the tour expenditure are covered by government departments or state-run organisations under the requirement of the central government" [Li and Hu, (2008), p.157].

Both 'green' and 'heritage' strategies are formulated to answer the call for a sustainable and balanced development from a people-centred approach, with tourism being considered a driving force in reducing rural-urban and regional inequalities, bearing in mind that the surrounding environment is largely rural (Ryan et al., 2009b), and at the same time aiming at being more environment friendly. In the context of the environmental deterioration, nature-based tourism has been developed and promoted to support biodiversity conservation (Wen and Tisdell, 2001).

Heritage tourism is prioritised to promote culture and heritage, and its integration into urban (re)development projects can be understood in the light of the socio-cultural turn of the new century. In 2009, CNTA and the Ministry of Culture jointly issued the Guide for the Integrated Development of Culture and Tourism. In line with this first policy document on cultural tourism, heritage consumption and heritage tourism development have been greatly promoted (Economic Daily, 2009). However, at the same time, the promotion of heritage consumption and cultural industry development for the sake of tourism tends to value heritage still largely in economic terms, which may weaken and complicate heritage conservation, as seen in the construction of antique-style buildings.

\subsection{Towards a more balanced and integrated relation?}

The new century has seen continued conflicts between heritage conservation and urban development, but at the same time an improved negotiation power of heritage in the light of the socio-cultural development goals. With more interactions and dynamics, a sound and integrated agenda for tourism, heritage and urban development seems to be on the way. The regime in this period features a more balanced power relation and a more 
pronounced role of tourism present as a socio-cultural mediator, though the economic tie is still prominent.

The friction between heritage and urban development starts to be faced, acknowledged and tackled (Shan, 2006). Heritage conservation has been placed on the agenda. The legal documents issued in the period of 2000-2008 have exceeded the total number from the previous 50 years $(\mathrm{SACH}, 2009)$. Among them, more than ten documents address the issues concerning planning and urban construction work (SACH, 2009). In 2000 and 2006, SACH and the Ministry of Construction organised, together with UNESCO and the World Bank, two international conferences on cultural heritage management and urban development to meet heritage conservation challenges brought along by the rapid urban development process.

Heritage and tourism have been brought closer. The word 'tourism' has started to appear in official heritage documents and regulations since the new century (SACH, 2009). In 2009, CNTA and the Ministry of Culture, for the first time, jointly issued the Guide for the Integrated Development of Culture and Tourism. In addition to the cross-sector administrative cooperation, private companies become very active as well in heritage management, heritage tourism development and the cultural industry, in cooperation with government bodies. Some municipalities or districts have their own tourism development companies or cultural industry companies. In this manner, government bodies tend to develop more discourse power over the issues concerned.

The balanced and scientific development thinking has furthered the tourism development and its interaction with heritage and urban development, with tourism being considered a driving force in the socio-economic development (Ryan et al., 2009b). Many conservation and urban development projects are integrated via tourism. The heritage theme park practice is one such example, which aims to protect heritage, stimulate economy, and improve neighbourhood environment and life quality. Nevertheless, the other voice underlines the gentrification of the areas around the heritage parks or the threat to heritage from over-commercialisation.

In the previous period, urban development and heritage were related mostly via tourism in economic terms, often at the expense of culture and heritage. This period advocates a cultural bond among the sustainable urban development and tourism development, and the recognised cultural value of heritage (Economic Daily, 2009; Hu, 2007). Together with the acknowledged socio-cultural role of tourism, a dynamic relation among the three starts to appear, with each possessing some negotiation power in cooperation. Thus, with the social-cultural turn, the three elements may be approached and practiced in a more balanced and sustainable way. Meanwhile, this still depends on the national socio-economic contexts and the determination of the state to put ideas into practice.

\section{Conclusions}

The tourism development in China was and is still largely top-down by nature. The centralised political structure and socialist economic system suggest a vital role played by the central government and national policy making. To understand China's tourism development without understanding the state will never end up complete. However, the state itself does not give the complete picture either. The regime approach adopted allows 
us to investigate China's tourism development in the light of its contextual background, but at the same time provides space for examining the internal dynamics in the process.

The tourism development in China has undergone a process of transformation: from 'nothing' to 'something', from state command to actor cooperation, and from a perceived mono-functional cause to a multi-functional industry. Though advocated as a multi-functional industry, perhaps its economic role continues to be of paramount importance. In 1998, the tourism industry was considered as a new growth point in the national economy for the first time. In the 2004 National Tourism Works Conference, the economic role of tourism was emphasised again in addition to its socio-cultural and political functions. Four years later in 2008, tourism was upgraded once more to be a strategic industry in the national economy. The emphasis of tourism's increasing economic importance and its perceived role as a multi-functional industry seem to mismatch; however, this shows also the struggle of the state to achieve a balance among all kinds of interests. The current national socio-economic contexts and the determination of the state to translate words into action play a decisive part. In this regard, China is still on the way to a sustainable and balanced tourism development.

Tourism's relation with heritage and urban development experiences changes too. In the pre-reform period, the focus on political struggle and industrialisation gave tourism and culture little role to play. No direct link existed among them but the destruction of heritage to give way to industrialisation and development. The post-reform period saw rapid urban development and tourism development and more conservation efforts. With the economic development prioritised, the relation among the three seemed grounded in the economic logic. As a result, heritage had been greatly threatened and commoditised by both urban development and tourism. Though linking heritage and urban development, tourism, via the economic tie, failed to play a mediating role in the frictions between heritage conservation and urban development. The destruction and commoditisation of heritage in this period have led to the new strategies taken since around the new century, including raising public awareness, issuing relevant legal documents, and highlighting heritage's cultural value. In addition, with the changing national and international environment, the sustainable development propaganda, and the recognised importance of culture in the new century, heritage has received some discourse power in the negotiation. At the same time, the role of tourism in leading socio-cultural and economic development becomes more pronounced, especially in places rich in heritage. It is under these circumstances that tourism's mediating role seems to be made possible. However, one still needs to wait and see whether tourism can actually serve as a lever and whether a more balanced and sustained relation among tourism, heritage and urban development can be achieved. Thus, an in-depth analysis of the relationship between tourism and heritage at heritage sites in China is recommended and is part of our long-term research agenda.

\section{Acknowledgements}

This work was supported by the China Scholarship Council under Grant [201208610195]. 


\section{References}

Airey, D. and Chong, K. (2011) Tourism in China: Policy and Development Since 1949, Routledge, London and New York.

Arlt, W.G. (2006) China's Outbound Tourism, Routledge, London and New York.

Ball, S., Horner, S. and Nield, K. (2007) Contemporary Hospitality and Tourism Management Issues in China and India: Today's Dragons and Tigers, Elsevier, Amsterdam.

Cao, B. (2002) 'Heritage conservation in heritage tourism', Wenwu Gongzuo, No. 10, pp.16-20, in Chinese.

Chen, L. (2003) 'A review of cultural heritage protection in contemporary China', Journal of Zhejiang Provincial CPC School, No. 3, pp.70-75, in Chinese.

China Economy (2014) Wang Xingbin: Urbanization is the Foundation of Domestic Tourism, 19 June, in Chinese [online] http://www.ce.cn/culture/gd/201406/19/t20140619_3000407. shtml (accessed 24 October 2015).

Collins, T.W. (2008) 'Unevenness in urban governance: stadium building and downtown redevelopment in Phoenix, Arizona', Environment and Planning C: Government and Policy, Vol. 26, No. 6, pp.1177-1196.

DiGaetano, A. and Klemanski, J.S. (1993) 'Urban regimes in comparative perspective: the politics of urban development in Britain', Urban Affairs Quarterly, Vol. 29, No. 1, pp.54-83.

Dikőtter, F. (2010) Mao's Great Famine: The History of China's Most Devastating Catastrophe, 1958-1962, Walker, New York.

Economic Daily (2009) Integrated Development of Culture and Tourism to a New Level, 1 January, in Chinese [online] http://paper.ce.cn/jjrb/html/2009-11/01/content_85816.htm (accessed 23 June 2014).

Edwards, A. and Prins, R. (2014) 'Policing and crime in contemporary London: a developmental agenda?', European Journal of Policing Studies, Vol. 2, No. 1, pp.61-93.

Elkin, S.L. (1985) 'Twentieth century urban regimes', Journal of Urban Affairs, Vol. 7, No. 2, pp.11-28.

Fainstein, S.S., Fainstein, N.I., Child-Hill, R., Judd, D. and Smith, M.P. (1983) Restructuring the City: The Political Economy of Urban Redevelopment, Longman, New York.

Gao, D. and Zhang, G. (1983) 'China's tourism: policy and practice', Tourism Management, Vol. 4, No. 2, pp.75-84.

Gjerde, K.M., Dotinga, H., Hart, S., Molenaar, E.J., Rayfuse, R. and Warner, R. (2008) Regulatory and Governance Gaps in the International Regime for the Conservation and Sustainable Use of Marine Biodiversity in Areas beyond National Jurisdiction, IUCN, Gland, Switzerland.

Haas, E.B. (1980a) 'Technological self-reliance for Latin America: the OAS contribution', International Organization, Vol. 34, No. 4, pp.541-570.

Haas, E.B. (1980b) 'Why collaborate?: issue-linkage and international regimes', World Politics, Vol. 32, No. 3, pp.357-405.

Haggard, S. and Simmons, B.A. (1987) 'Theories of international regimes', International Organization, Vol. 41, No. 3, pp.491-517.

Hall, D.R. (2001) 'Tourism and development in communist and post-communist societies', in Harrison, D. (Ed.): Tourism and the Less Developed World: Issues and Case Studies, pp.91-107, CABI, Wallingford.

Han, K. (Ed.) (2009) Contemporary China: Tourism Industry, in Chinese, Contemporary China Publishing House, Beijing.

Hasenclever, A., Mayer, P. and Rittberger, V. (Eds.) (1997) Theories of International Regimes, Cambridge University Press, Cambridge.

He, G. (2005) 'Developing red tourism and improving three-culture construction', Qiu Shi, No. 7, pp.53-56, in Chinese. 
Henig, J.R., Hula, R.C., Orr, M. and Pedescleaux, D.S. (1999) The Color of School Reform: Race, Politics, and the Challenge of Urban Education, Princeton University Press, Princeton, NJ.

Hu, J. 2007. Report in the 17th National Congress of People's Republic of China, in Chinese [online] http://www.gov.cn/ldhd/2007-10/24/content_785431.htm (accessed 10 November 2013).

Inbar, E. (Ed.) (1995) Regional Security Regimes: Israel and Its Neighbors, State University of New York Press, Albany.

Jones, T.C. and Dugdale, D. (2001) 'The concept of an accounting regime', Critical Perspectives on Accounting, Vol. 12, No. 1, pp.35-63.

Keohane, R.O. and Nye, J.S. (1977) Power and Interdependence: World Politics in Transition, Little, Brown, Boston.

Konrad, K., Truffer, B. and Voß, J. (2008) 'Multi-regime dynamics in the analysis of sectoral transformation potentials: evidence from German utility sectors', Journal of Cleaner Production, Vol. 16, No. 11, pp.1190-1202.

Krasner, S.D. (1982a) 'Regimes and the limits of realism: regimes as autonomous variables', International Organization, Vol. 36, No. 2, pp.497-510.

Krasner, S.D. (1982b) 'Structural causes and regime consequences: regimes as intervening variables', International Organization, Vol. 36, No. 2, pp.185-205.

Lauria, M. (Ed.) (1997) Reconstructing Urban Regime Theory: Regulating Urban Politics in a Global Economy, Sage, Thousand Oaks, CA.

Levy, M.A., Young, O.R. and Zurn, M. (1995) 'The study of international regimes', European Journal of International Relations, Vol. 1, No. 3, pp.267-330.

Lew, A.A. and Yu, L. (1995) 'Organization', in Lew, A.A. and Yu, L. (Eds.): Tourism in China: Geographic, Political, and Economic Perspectives, 61pp, Westview Press, Boulder, CO.

Li, X. and Wang, W. (2000) 'My opinions on artificial landscape architecture of scenic sports', New Architecture, No. 6, pp.24-26, in Chinese.

Li, Y. and Hu, Z. (2008) 'Red tourism in China', Journal of China Tourism Research, Vol. 4, No. 2, pp.156-171.

Lin, J.Y. (1987) 'The household responsibility system reform in China: a peasant's institutional choice', American Journal of Agricultural Economics, Vol. 69, No. 2, pp.410-415.

Lin, J.Y. (1988) 'The household responsibility system in China's agricultural reform: a theoretical and empirical study', Economic Development and Cultural Change, Vol. 36, No. 3, pp.199-224.

Ma, L.J.C. and Wu, F. (Eds.) (2005) Restructuring the Chinese City: Changing Society, Economy and Space, Routledge, London and New York.

Maswood, S.J. (2000) 'Kakadu and the politics of world heritage listing', Australian Journal of International Affairs, Vol. 54, No. 3, pp.357-372.

Mossberger, K. and Stoker, G. (2001) 'The evolution of urban regime theory: the challenge of conceptualization', Urban Affairs Review, Vol. 36, No. 6, pp.810-835.

Nee, V. (1996) 'The emergence of a market society: changing mechanisms of stratification in China', American Journal of Sociology, Vol. 101, No. 4, pp.908-949.

Ploberger, C. (2012) 'Analysing complex political change by applying the concept of regime change: identifying the transformations within the Japanese political-bureaucratic-business regime', Asian Social Science, Vol. 8, No. 15, pp.12-23.

Porter, T. (2002) 'Politics, institutions, constructivism and the emerging international regime for financial regulation', The Review of Policy Research, Vol. 19, No. 1, pp.53-79.

Qiao, Y. (1995) 'Domestic tourism in China: policies and development', in Lew, A. and Yu, L. (Eds.): Tourism in China: Geographic, Political and Economic Perspectives, pp.121-130, Westview Press, Boulder, CO.

Richter, L.K. (1989) The Politics of Tourism in Asia, University of Hawaii Press, Honolulu. 
Ruggie, J.G. (1975) 'International responses to technology: concepts and trends', International Organization, Vol. 29, No. 3, pp.557-583.

Ryan, C., Gu, H. and Meng, F. (2009a) 'Destination planning in China', in Ryan, C. and Gu, H. (Eds.): Tourism in China: Destination, Cultures and Communities, pp.11-37, Routledge, New York.

Ryan, C., Gu, H. and Zhang, W. (2009b) 'The context of Chinese tourism: an overview and implications for research', in Ryan, C. and Gu, H. (Eds.): Tourism in China: Destination, Cultures and Communities, pp.327-336, Routledge, New York.

Saich, T. (2004) Governance and Politics of China, 2nd ed., Palgrave Macmillan, New York.

Shan, J. (2006) Urban Development and Cultural Heritage Protection, in Chinese, Tianjin University Press, Tianjin.

Shan, J. (2010) Retaining the Cultural Root and Soul of the City: Exploration and Practice of China's Cultural Heritage Protection, in Chinese, China Science Press, Beijing.

Shepherd, R.J. and Yu, L. (2013) Heritage Management, Tourism, and Governance in China: Managing the Past to Serve the Present, Springer, New York.

Sofield, T.H.B. and Li, F.M.S. (1998) 'Tourism development and cultural policies in China', Annals of Tourism Research, Vol. 25, No. 2, pp.362-392.

Stokke, O.S., Hovi, J. and Ulfstein, G. (Eds.) (2005) Implementing the Climate Regime: International Compliance, Earthscan, London.

Stone, C.N. (1989) Regime Politics: Governing Atlanta, 1946-1988, University Press of Kansas, Lawrence.

Stone, C.N. (1993) 'Urban regimes and the capacity to govern: a political economy approach', Journal of Urban Affairs, Vol. 15, No. 1, pp.1-28.

Stone, C.N. (1998) 'Introduction: urban education in political context', in Stone, C.N. (Ed.): Changing Urban Education, pp.1-20, University Press of Kansas, Lawrence.

$\mathrm{Su}, \mathrm{X}$. (2015) 'Urban entrepreneurialism and the commodification of heritage in China', Urban Studies, Vol. 52, No. 15, pp.2874-2889.

The China National Bureau of Statistics (CNBS) (2015) Statistical Bulletin on the National Economic and Social Development 2014, CNBS, Beijing [online] http://www.stats.gov.cn/tjsj/ $\mathrm{zxfb} / 201502 / \mathrm{t} 20150226 \_685799 . \mathrm{html}$ (accessed 26 October 2015).

The China National Tourism Administration (CNTA) (1996) The Yearbook of China Tourism Statistics, in Chinese, China Travel \& Tourism Press, Beijing.

The China National Tourism Administration (CNTA) (2001) The Yearbook of China Tourism Statistics, in Chinese, China Travel \& Tourism Press, Beijing.

The Communist Party of China (CPC) (1978) 'Communique of the third plenary session of the 11th central committee of the Communist Party of China', Peking Review, Vol. 21, No. 52, pp.6-16.

The Communist Party of China (CPC) (2011) Decision of the CPC Central Committee on Major Issues Pertaining to Deepening Reform of the Cultural System and Promoting the Great Development and Flourishing of Socialist Culture, [online] http://www.cctb.net/bygz/wxfy/201111/t20111117_30877.htm (accessed 12 June 2015).

The General Office of the Communist Party of China and the General Office of the State Council (GOCPC and GOSC) (2004) Red Tourism Development Plan 2004-2010, in Chinese [online] http://www.sdpc.gov.cn/fzgggz/fzgh/ghwb/gjjgh/200709/P020150630514113129776.pdf (accessed 18 November 2015).

The General Office of the Communist Party of China and the General Office of the State Council (GOCPC and GOSC) (2011) Red Tourism Development Plan 2011-2015, in Chinese [online] http://jpzy.hbtvc.com/course/dyzs/doc-279-view-159.aspx (accessed 18 November 2015).

The Ministry of Culture and the China National Tourism Administration (MC and CNTA) (2009) The Guide for the Integrated Development of Culture and Tourism, in Chinese [online] http://www.gov.cn/zwgk/2009-09/15/content_1418269.htm (accessed 10 November 2015). 
The State Administration of Cultural Heritage (SACH) (2009) Legal Documents on Heritage Conservation in China: 1949-2009, in Chinese, Cultural Relics Press, Beijing.

The State Council (SC) (2001) Notice on Further Strengthening the Tourism Development, in Chinese [online] http://www.gov.cn/gongbao/content/2001/content_60814.htm (accessed 26 October 2015).

The State Council (SC) (2014) National New-type Urbanization Plan (2014-2020), in Chinese [online] http://www.gov.cn/gongbao/content/2014/content_2644805.htm (accessed 15 November 2015).

The World Bank (WB) (2016) The World Development Indicators [online] http://data.worldbank. org/indicator/NV.SRV.TETC.ZS?page=6 (accessed 25 April 2016).

Tretter, E.M. (2008) 'Scales, regimes, and the urban governance of Glasgow', Journal of Urban Affairs, Vol. 30, No. 1, pp.87-102.

UNWTO (2015) UNWTO Tourism Highlights [online] http://www.e-unwto.org/doi/pdf/10.18111/ 9789284416899 (accessed 10 October 2015).

Ward, K. (1996) 'Rereading urban regime theory: a sympathetic critique', Geoforum, Vol. 27, No. 4, pp.427-438.

Wen, J.J. and Tisdell, C.A. (2001) Tourism and China's Development: Policies, Regional Economic Growth and Ecotourism, World Scientific, Singapore.

Whitehand, J.W.R. and Gu, K. (2007) 'Urban conservation in China: historical development, current practice and morphological approach', Town Planning Review, Vol. 78, No. 5, pp.643-670.

World Economic Forum (2015) The Travel \& Tourism Competitiveness Report 2015: Growth through Shocks, World Economic Forum, Geneva.

Wu, B., Zhu, H. and Xu, X. (2000) 'Trends in China's domestic tourism development at the turn of the century', International Journal of Contemporary Hospitality Management, Vol. 12, No. 5, pp.296-299.

Xiao, H. (2006) 'The discourse of power: Deng Xiaoping and tourism development in China', Tourism Management, Vol. 27, No. 5, pp.803-814.

$\mathrm{Xu}, \mathrm{G}$. (2016) The Great Ruins Protection and the State Archaeological Ruins Park, in Chinese [online] http://www.ccrnews.com.cn/index.php/Index/content/id/59741.html (accessed 23 March 2016).

Yan, H. and Bramwell, B. (2008) 'Cultural tourism, ceremony and the state in China', Annals of Tourism Research, Vol. 35, No. 4, pp.969-989.

Young, O.R. (1980) 'International regimes: problems of concept formation', World Politics, Vol. 32, No. 3, pp.331-356.

Young, O.R. (1982) 'Regime dynamics: the rise and fall of international regimes', International Organization, Vol. 36, No. 2, pp.277-297.

Zhang, G. (1989) 'Ten years of Chinese tourism: profile and assessment', Tourism Management, Vol. 19, No. 1, pp.51-62.

Zhang, G. (1995) 'China's tourism since 1978: policies, experiences, and lessons learned', in Lew, A. and Yu, L. (Eds.): Tourism in China: Geographic, Political and Economic Perspectives, pp.3-17, Westview Press, Boulder, CO.

Zhang, G. and Lew, A. (2003) 'Introduction: China's tourism boom', in Lew, A., Yu, L., Ap, J. and Zhang, G. (Eds.): Tourism in China, pp.3-11, The Haworth Press, New York.

Zhang, H.Q., Chong, K. and Ap, J. (1999) 'An analysis of tourism policy development in modern China', Tourism Management, Vol. 20, No. 4, pp.471-485.

Zhang, L. (1999) 'Chinese central-provincial fiscal relationships, budgetary decline and the impact of the 1994 fiscal reform: an evaluation', The China Quarterly, Vol. 157, pp.115-141.

Zhen, J. (2009) 'Xie Chensheng: I have determined to die on duty', South Reviews, No. 10, pp.66-69, in Chinese. 
Zhu, J. (2004) 'Local developmental state and order in China's urban development during transition', International Journal of Urban and Regional Research, Vol. 28, No. 2, pp.424-447.

\section{Notes}

1 Haggard and Simmons (1987) identified four schools of thoughts: structural, game-theoretic, functional, and cognitive, which correspond to conventional structural, modified structural, modified structural and Grotian in Krasner's (1982b) formulation. Later, Hasenclever et al. (1997) classified different schools into realism, neoliberalism, and cognitivism with power-based, interest-based and knowledge-based approaches respectively.

2 Non-administrative organisations, the so-called shiye danwei, are non-profit entities supervised by relevant government agencies. Thus, similar with state-owned enterprises, they form also part of the hierarchical administrative structure. For more, see Airey and Chong, 2011.

3 The household responsibility system replaces collective farming with individual household farming through long-term contracts, while the public ownership of the land remains unchanged. In this system, farmers are granted autonomy in terms of production and management, and thus responsible for the profits and losses. This measure helps enhance farmers' production initiative, increase agricultural productivity and diversify the rural economy. For more, see Lin $(1987,1988)$. 